\title{
PENGARUH KUALITAS PRODUK, PROMOSI DAN DESAIN TERHADAP KEPUTUSAN PEMBELIAN KENDARAAN BERMOTOR YAMAHA MIO PADA PT. HASJRAT ABADI KOTA JAYAPURA
}

\author{
Wilem Kimkuri* dan Benyamin Buntu, SE., M.Si** \\ *Mahasiswa Prodi Manajemen, STIE Port Numbay Jayapura \\ ** Dosen Prodi Manajemen, STIE Port Numbay Jayapura
}

\begin{abstract}
The purpose of this study was to determine the effect of product quality, promotion and design of Yamaha Mio motor vehicles on purchasing decisions at PT. Hasjrat Abadi Jayapura City, with a total of 65 respondents. Based on the results of the study, it can be seen that: 1. Product quality has a positive and significant effect on purchasing decisions for Yamaha Mio motor vehicles at PT. Jayapura City's Eternal Hasjrat. 2. Promotion has a positive and significant effect on purchasing decisions for Yamaha mio motor vehicles at PT. Jayapura City's Eternal Hasjrat. 3. Design has a positive and significant effect on purchasing decisions for Yamaha Mio motor vehicles at PT. Jayapura City's Eternal Hasjrat. 4. Product quality, promotion and design simultaneously have a positive and significant effect on purchasing decisions for Yamaha Mio motor vehicles at PT. Jayapura City's Eternal Hasjrat.
\end{abstract}

Keywords: Product Quality, Promotion, Design, Purchase Decision

Abstrak: Tujuan dari penelitian ini adalah untuk mengetahui pengaruh kualitas produk, promosi dan desain kendaraan bermotor yamaha mio terhadap keputusan pembelian pada PT. Hasjrat Abadi Kota Jayapura, dengan jumlah responden sebanyak 65 orang. Berdasarkan hasil penelitian dapat terlihat bahwa : 1. kualitas produk berpengaruh positif dan signifikan terhadap keputusan pembelian kendaraan bermotor yamaha mio pada PT. Hasjrat Abadi Kota Jayapura. 2. Promosi berpengaruh positif dan signifikan terhadap keputusan pembelian kendaraan bermotor Yamaha mio pada PT. Hasjrat Abadi Kota Jayapura. 3. Desain berpengaruh positif dan signifikan terhadap keputusan pembelian kendaraan bermotor yamaha mio pada PT. Hasjrat Abadi Kota Jayapura. 4. Kualitas produk, promosi dan desain secara simultan berpengaruh positif dan signifikan terhadap keputusan pembelian kendaraan bermotor yamaha mio pada PT. Hasjrat Abadi Kota Jayapura.

Kata Kunci : Kualitas Produk, Promosi, Desain, Keputusan Pembelian

\section{Latar Belakang}

PT Hasjrat Abadi ("Hasjrat") adalah adalah perusahaan dinamis yang menjual kendaraan dan aksesoris Toyota dan Yamaha, suku cadang asli, servis kendaraan, dan pilihan pembiayaan yang sistematis dengan pelanggan di Indonesia Timur. Serta distributor eksklusif kendaraan Toyota dan Yamaha di sebelas propinsi terkemuka, wilayah Indonesia bagian Tengah \& Timur. Di tengah-tengah persaingan yang begitu tajam akibat banyaknya merek pendatang baru, sepeda motor Yamaha cukup mendominasi pasar dan memenuhi kebutuhan angkutan yang tangguh, irit dan ekonomis. Yamahapun mengembangkan teknologi yang mampu memenuhi kebutuhan pelanggan yaitu mesin bandel dan irit bahan bakar sehingga menjadikannya sebagai pelopor kendaraan roda dua yang ekonomis. Persaingan bisnis yang semakin tajam yang terlibat langsung di pasar merupakan ancaman yang sering ditemui oleh perusahaan baik produk lokal, nasional dan internasional. Perusahaan dituntut lebih kreatif untuk memanfaatkan peluang yang ada. Salah satu usaha yang dapat dilakukan adalah dengan mengetahui, mencari, menganalisa apa yang menjadi penyebab dari kegagalan peningkatan penjualan. Faktor yang mempengaruh peningkatan penjualan sangat beragam, baik faktor internal dari kegiatan pemasaran perusahaan (kualitas produk, harga, distribusi dan promosi) maupun faktor eksternal yang terkait dengan keputusan pembelian konsumen dalam memilih suatu produk (Husain, 2011). Data penjualan sepeda motor menurut Asosiasi Industri Sepedamotor Indonesia (AISI) berdasarkan penjualan per unit, dapat dilihat pada tabel berikut :

Data Penjualan Per Unit

\begin{tabular}{|c|r|r|r|r|c|}
\hline \multirow{2}{*}{ Pabrikan } & \multicolumn{3}{|c|}{ Penjualan/Unit } & \multirow{2}{*}{ Jumlah } & \multirow{2}{*}{$\%$} \\
\cline { 2 - 4 } & $\mathbf{2 0 1 7}$ & $\mathbf{2 0 1 8}$ & $\mathbf{2 0 1 9}$ & & \\
\hline 1. Honda & 4.385 .888 & 4.759 .202 & 4.910 .688 & 14.055 .778 & 74,94 \\
\hline 2. Yamaha & 1.348 .211 & 1.455 .088 & 1.434 .217 & 4.237 .516 & 22,59 \\
\hline 3. Kawasaki & 78.637 & 89.508 & 71.861 & 240.006 & 1,28 \\
\hline 4. Suzuki & 72.191 & 78.982 & 69.766 & 220.939 & 1,18 \\
\hline 5. TVS & 1.176 & 331 & 898 & 2.405 & 0,01 \\
\hline Total & $\mathbf{5 . 8 8 6 . 1 0 3}$ & $\mathbf{6 . 3 8 3 . 1 1 1}$ & $\mathbf{6 . 4 8 7 . 4 3 0}$ & $\mathbf{1 8 . 7 5 6 . 6 4 4}$ & $\mathbf{1 0 0}$ \\
\hline Sumber & $\mathrm{h}$ & & & & \\
\hline
\end{tabular}

Sumber : https://aripitstop.com/2020/01/21/intip-datapenjualan-motor-di-indonesia-tahun-2017-

2019-kapan-penjualan-honda-bisa-turun/

Dari tabel di atas menunjukan bahwa sepeda motor Yamaha dengan sepeda motor Honda masuk kedalam 5 besar penjualan sepeda motor matik pada Tahun 2019 di Indonesia. Dimana kedua perusahaan tersebut saling 
bersaing dalam memenuhi keinginan dan kebutuhan konsumen dengan keunggulan-keunggulan setiap produknya. Namun pada kenyataannya dari data di atas dapat dilihat bahwa perusahaan Yamaha khususnya jenis sepeda motor masih kalah dibandingkan dengan perusahaan pesaing (Honda). Meskipun pabrikan Yamaha pada masanya sebagai market leader kendaraan roda dua dengan sistem automatic, akan tetapi kondisi yang terjadi saat ini yaitu menurunnya pamor Yamaha berimbas pada penjualan produk. Kekalahan Yamaha dalam penjualan sepeda motor tersebut dapat terjadi karena berbagai hal, diantaranya yaitu semakin banyaknya konsumen Yamaha yang berpindah ke merek pesaing, mahalnya biaya aksesoris, sistem pembelian yang memerlukan waktu yang relatif lama, dan lain sebagainya.

Kualitas produk dari suatu barang maupun jasa juga menjadi salah satu faktor yang menjadi pertimbangan bagi para konsumen untuk melakukan pembelian. Kualitas produk merupakan kemampuan yang dimiliki oleh suatu produk guna menjalankan fungsinya yang mencakup ketepatan, keandalan, daya tahan, kemudahan operasi dan perbaikan serta atribut lainnya yang terdapat pada suatu produk (Kottler, 2001).

Seiring dengan perkembangan zaman, maka produsen harus senantiasa melakukan pengawasan terhadap kualitas dari suatu produk. Maka dari itu peerusahaan diharapkan dapat melakukan promosi yang dapat membuat konsumen mengetahui bagaimana produk sepeda motor matic merek Yamaha Mio sehingga dapat dikenal oleh konsumen. Kegiatan promosi tidak hanya sebagai alat komunikasin saja melainkan alat untuk mempengaruhi konsumen agar dapat melakukan keputusan pembelian. Oleh karena itu kegiatan promosi harus dilakukan semenarik mungkin agar konsumen ikut tertarik untuk melakukan keputusan pembelian. Promosi adalah salah satu variabel dalam bauran pemasaran yang sangat penting dilaksanakan oleh perusahaan dalam memasarkan suatu produk (Lupiyoadi, 2013).

Selain kualitas produk dan promosi, desain produk juga tidak kalah pentingnya untuk menarik konsumen. Jika desain produk itu bagus dan menarik, maka konsumen akan dengan senang hati melakukan keputusan pembelian terhadap sepeda motor matic merek Yamaha Mio. Tujuan perusahaan memperbaiki desain produk yakni agar konsumen tertarik untuk membeli produk tersebut. Desain produk merupakan suatu kualitas produk dalam isyarat ekstrinsik salah satunya berupa bentuk maupun tampilan, rancangan tampilan desain sangat penting bagi perusahaan untuk produk yang akan dipasarkan karena menyangkut kesesuaian daya tarik konsumen untuk tertarik dan membelinya (Kottler, 2012).

\section{Tujuan Penelitian}

1) Untuk mengetahui pengaruh kualitas produk terhadap keputusan pembelian kendaraan bermotor Yamaha Mio Pada PT. Hasjrat Abadi Kota Jayapura.

2) Untuk mengetahui pengaruh promosi terhadap keputusan pembelian kendaraan bermotor Yamaha Mio Pada PT. Hasjrat Abadi Kota Jayapura.
3) Untuk mengetahui pengaruh desain terhadap keputusan pembelian kendaraan bermotor Yamaha Mio Pada PT. Hasjrat Abadi Kota Jayapura.

4) Untuk mengetahui pengaruh kualitas prosuk, promosi dan desain secara bersama-sama terhadap keputusan pembelian kendaraan bermotor Yamaha Mio Pada PT. Hasjrat Abadi Kota Jayapura.

\section{Kajian Teori}

\section{Kualitas Produk}

Kasmir (2005) menyatakan bahwa produk atau jasa adalah sesuatu yang ditawarkan kepada konsumen nasabah untuk mendapatkan perhatian, untuk dimiliki, digunakan atau dikonsumsi dalam rangka memenuhi kebutuhan dan keinginan nasabah. Pengertian umum produk adalah segala sesuatu yang dapat ditawarkan ke pasar untuk mendapatkan perhatian, dibeli, dipergunakan atau dikonsumsi dan yang dapat memuaskan kebutuhan dan keinginan.

Faktor-faktor yang Mempengaruhi Kualitas Produk

Dalam hal mutu suatu produk yang dihasilkan oleh suatu perusahaan kadang mengalami keragaman. Hal ini disebabkan mutu suatu produk itu dipengaruhi oleh beberapa faktor, dimana faktor-faktor ini dapat menentukan bahwa suatu produk dapat memenuhi standar yang telah ditentukan atau tidak, faktor-faktor tersebut antara lain :

1) Manusia

Peranan manusia atau karyawan yang bertugas dalam perusahaan akan sangat mempengaruhi secara langsung terhadap baik buruknya mutu dari produk yang dihasilkan oleh suatu perusahaan. Maka aspek manusia perlu mendapat perhatian yang cukup. Perhatian tersebut dengan mengadakan latihan-latihan, pemberian motivasi, pemberian jamsostek, kesejahteraan, dan lain lain.

2) Manajemen

Tanggung jawab atas mutu produksi dalam perusahaan dibebankan dalam bebarapa kelompok yang biasa disebut dengan Function Group. Dalam hal ini pimpinan harus melakukan koordinasi yang baik antara fungtion group dengan bagian-bagian lainnya dalam perusahaan tersebut. Dengan adanya koordinasi tersebut maka dapat tercapai suasana kerja yang baik dan harmonis, serta menghindarkan adanya kekacauan dalam pekerjaan. Keadaan ini memungkinkan perusahaan untuk mempertahankan mutu serta meningkatkan mutu dari produk yang dihasilkan.

3) Uang

Perusahaan harus menyediakan uang yang cukup untuk mempertahankan atau meningkatkan mutu produknya. Misalnya: untuk perawatan dan perbaikan mesin atau peralatan produksi, perbaikan produk yang rusak, dan lain-lain.

4) Bahan baku

Bahan baku merupakan salah satu faktor yang sangat penting dan akan mempengaruhi mutu suatu produk yang dihasilkan suatu perusahaan. Untuk itu pengendalian mutu bahan baku menjadi hal yang sangat penting dalam hal bahan baku, harus memperhatikan beberapa hal antara lain: seleksi sumber dari bahan baku, pemeriksaan dokumen pembelian, pemeriksaan 
penerimaan bahan baku, serta penyimpanan. Hal hal tersebut harus dilakukan dengan baik sehingga kemungkinan bahan baku yang akan digunakan untuk proses produksi berkualitas rendah dapat ditekan sekecil mungkin.

5) Mesin dan peralatan

Mesin serta peralatan yang digunakan dalam proses produksi akan mempengaruhi terhadap mutu produk yang dihasilkan perusahaan. Peralatan yang kurang lengkap serta mesin yang sudah kuno dan tidak ekonomis akan menyebabkan rendahnya mutu dan produk yang dihasilkan, serta tingkat efisiensi yang rendah. Akibatnya biaya produksi menjadi tinggi, sedangkan produk yang dihasilkan kemungkinan tidak akan laku dipasarkan. Hal ini akan mengakibatkan perusahaan tidak dapat bersaing dengan perusahaan lain yang sejenis, yang menggunakan mesin dan peralatan otomatis.

\section{1) Manfaat Kualitas Produk}

Menurut Ariani (2003), terdapat beberapa manfaat yang diperoleh dengan menciptakan kualitas produk yang baik, yaitu:

1) Meningkatkan reputasi perusahaan. Perusahaan atau organisasi yang telah menghasilkan suatu produk atau jasa yang berkualitas akan mendapatkan predikat sebagai organisasi yang mengutamakan kualitas, oleh karena itu, perusahaan atau organisasi tersebut dikenal oleh masyarakat luas dan mendapatkan nilai lebih di mata masyarakat.

2) Menurunkan biaya. Untuk menghasilkan produk atau jasa yang berkualitas perusahaan atau organisasi tidak perlu mengeluarkan biaya tinggi. Hal ini disebabkan perusahaan atau organisasi tersebut berorientasi pada (customer satisfaction), yaitu dengan mendasarkan jenis, tipe, waktu, dan jumlah produk yang dihasilkan sesuai dengan harapan dan kebutuhan konsumen.

3) Meningkatkan pangsa pasar. Pangsa pasar akan meningkat bila minimasi biaya tercapai, karena organisasi atau perusahaan dapat menekan harga, walaupun kualitas tetap menjadi yang utama.

4) Dampak internasional. Bila mampu menawarkan produk atau jasa yang berkualitas, maka selain dikenal di pasar lokal, produk atau jasa tersebut juga akan dikenal dan diterima di pasar internasional.

5) Adanya tanggung jawab produk. Dengan semakin meningkatnya persaingan kualitas produk atau jasa yang dihasilkan, maka organisasi atau perusahaan akan dituntut untuk semakin bertanggung jawab terhadap desain, proses, dan pendistribusian produk tersebut untuk memenuhi kebutuhan konsumen.

6) Untuk penampilan produk. Kualitas akan membuat produk atau jasa dikenal, dalam hal ini akan membuat perusahaan yang menghasilkan produk juga akan dikenal dan dipercaya masyarakat luas.

7) Mewujudkan kualitas yang dirasakan penting. Persaingan yang saat ini bukan lagi masalah harga melainkan kualitas produk, hal inilah yang mendorong konsumen untuk mau membeli produk dengan harga tinggi namun dengan kualitas yang tinggi pula.

\section{2) Perspektif Kualitas Produk}

Perspektif kualitas produk merupakan persepsi seorang konsumen terhadap keseluruhan kualitas atau keunggulan suatu produk atau jasa dengan maksud yang diharapkan atau diinginkan oleh konsumen. Menurut Tjiptono (2012), terdapat lima jenis perspektif kualitas produk, yaitu :

1) Transcendental approach

Kualitas dalam pendekatan ini dapat dirasakan atau diketahui tetapi sulit didefinisikan dan dioperasionalkan. Sudut pandang ini biasanya diterapkan dalam seni musik, drama, seni tari, dan seni rupa. Selain perusahaan dapat mempromosikan produknya dengan pertanyaan-pertanyaan seperti tempat berbelanja yang menyenangkan (supermarket), elegan (mobil), kecantikan wajah (kosmetik) kelembutan dan kehalusan kulit (sabun mandi), dan lain-lain. Dengan demikian fungsi perencanaan, produksi, dan pelayanan suatu perusahaan sulit sekali menggunakan definisi ini sebagai dasar manajemen kualitas.

2) Product-based approach

Pendekatan ini menganggap bahwa kualitas sebagai karakterisktik atau atribut yang dapat dikuantifikasikan dan dapat diukur. Perbedaan dalam kualitas mencerminkan perbedaan dalam jumlah beberapa unsur atau atribut yang dimiliki produk. Karena pandangan ini sangat objektif, maka tidak dapat menjelaskan perbedaan dalam selera, kebutuhan, dan preferensi individual.

3) User-based approach

Pendekatan ini didasarkan pada pemikiran bahwa kualitas tergantung pada orang yang memandangnya, dan produk yang paling memuaskan referensi seseorang (misalnya perceived quality) merupakan produk yang berkualitas yang paling tinggi. Perspektif yang subjektif dan demand-oriented juga menyatakan bahwa pelanggan yang berbeda memiliki kebutuhan dan keinginan yang berbeda pula, sehingga kualitas bagi seseorang adalah sama dengan kepuasan maksimum yang dirasakan. Kepuasan seseorang tentu akan berbeda-beda pula, begitu juga dengan pandangan seseorang terhadap kualitas suatu produk pasti akan berbeda-beda pula pandangannya. Suatu produk yang dapat memenuhi keinginan dan kepuasan seseorang, belum tentu dapat memenuhi kepuasan orang lain.

4) Manufacturing-based approach

Perspektif ini bersifat supply-based dan terutama memperhatikan praktik-praktik perekayasaan dan pemanufakturan, serta mendefinisikan kualitas sebagai sama dengan persyaratannya. Dalam sektor jasa, dapat dikatakan kualitas bersifat operation-driven. Pendekatan ini berfokus pada penyesuaian spesifikasi yang dikembangkan secara internal, yang sering kali di dorong oleh tujuan peningkatan produktivitas dan penekanan biaya. Jadi yang menentukan kualitas adalah standar-standar yang ditetapkan perusahaan, bukan konsumen yang menggunakannya. 


\section{5) Value-based approach}

Pendekatan ini memandang kualitas dari segi nilai dan harga dengan mempertimbangkan trade-off antara kinerja dan harga, kualitas didefinisikan sebagai affordable excellence. Kualitas dalam perspektif ini bernilai relatif, sehingga produk yang memiliki kualitas paling tinggi belum tentu produk yang paling bernilai. Akan tetapi yang paling bernilai adalah produk atau jasa yang paling tepat dibeli.

2. Promosi

Menurut Argarini (2008) promosi merupakan sebuah aktivitas komunikasi yang bertujuan untuk mempelancar arus produk, barang atau jasa tertentu pada sebuah saluran distribusi. Sedangkan menurut Laksana (2013) promosi merupakan suatu kegiatan yang harus dilakukan oleh perusahaan dalam rangka melaksanakan program promosi bila ingin dikenal oleh konsumen secara luas dan sukses di pasar sasaran. Sedangkan menurut Tjiptono (2015) promosi merupakan elemen bauran pemasaran yang berfokus pada upaya menginformasikan, membujuk, dan mengingatkan kembali konsumen akan merek dan produk perusahaan.

\section{Tujuan Promosi}

Setiap perusahaan yang melakukan kegiatan promosi tentu tujuan utamanya adalah untuk mencari laba menurut Tjiptono (2015), pada umumnya kegiatan promosi harus mendasarkan kepada tujuan sebagai berikut :

1) Menginformasikan Kegiatan promosi yang bertujuan untuk berusaha menginformasikan konsumen akan merek atau produk tertentu baik itu produk maupun merek baru atau produk dan merek yang sudah lama tetapi belum luas terdengar oleh konsumen.

2) Membujuk Kegiatan promosi yang bersifat membujuk dan mendorong konsumen untuk melakukan pembelian atas produk yang ditawarkan. Perusahaan lebih mengutamakan penciptaan kesan positif kepada konsumen agar promosi dapat berpengaruh terhadap perilaku pembeli dalam waktu yang lama.

3) Mengingatkan Kegiatan promosi yang bersifat mengingatkan ini dilakukan untuk mempertahankan merek produk di hati masyarakat, dan mempertahankan pembeli yang akan melakukan transaksi pembelian secara terus-menerus.

\section{Fungsi Promosi}

Menurut Terence A. Shimp (2002) promosi memiliki fungsi-fungsi seperti :

1) Informing (memberikan informasi), promosi membuat konsumen sadar akan produk-produk baru, mendidik mereka tentang berbagai fitur dan manfaat merek, serta memfasilitasi penciptaan citra sebuah perusahaan yang menghasilkan produk atau jasa. Promosi menampilkan pesan informasi bernilai lainnya, baik untuk merek yang diiklankan maupun konsumennya, dengan dengan mengajarkan manfaat-manfaat baru dari merek yang telah ada.

2) Persuading (Membujuk), media promosi atau iklan yang baik akan mampu mempersuasi pelanggan untuk mencoba produk dan jasa yang ditawarkan. Terkadang persuasi berbentuk mempengaruhi permintaan primer, yakni menciptakan permintaan bagi keseluruhan kategori produk. Lebih sering, promosi berupaya untuk membangun permintaan sekunder, permintaan bagi merek perusahaan yang spresifik.

3) Reminding (mengingatkan), iklan menjaga agar merek perusahaan tetap segar dalam ingatan para konsumen. Saat kebutuhan muncul, yang berhubungan dengan produk dan jasa yang di iklankan, dampak promosi di masa lalu memungkinkan merek pengiklan hadirdi benak konsumen. Periklanan lebih jauh di demonstrasikan untuk mempengaruhi pengalihan merek dengan mengingatkan para konsumen yang di akhirakhir ini belum membeli merek yang tersedia dan mengandung atribut-atribut yang menguntungkan.

4) Adding Value (Menambah nilai), terdapat tiga cara mendasar dimana perusahaan bisa membeli nilai tambah bagi penawaran mereka, inovasi, penyempurnaan, kualitas, atau mengubah persepsi konsumen. Ketiga komponen nilai tambah tersebut benar-benar independen. Promosi yang efektif menyebabkan merek dipandang lebih elegan, lebih bergaya, lebih bergengsi dan bisa lebih unggul.

\section{Desain}

\section{Pengertian Desain}

Menurut Kotler (2003) Desain adalah suatu ide besar, yang meliputi desain produk, desain jasa, desain grafis, dan desain lingkungan. Desain merupakan sekumpulan alat dan konsep untuk membantu persiapan produk-produk dan jasa-jasa yang berhasil. Pengertian desain menurut Ulrich dan Eppinger (2008) berdasarkan keterangan dari Industrial Designers Society of America (IDSA) adalah layanan profesional dalam menciptakan dan mengembangkan konsep dan spesifikasi yang mengoptimalkan fungsi, nilai, dan tampilan produk dan sistem untuk saling menguntungkan antara pengguna dan produsen.

\section{Tujuan Desain}

Menurut Kotler (2008) tujuan dari desain produk itu sendiri adalah :

1) Untuk menghasilkan produk yang berkualitas tinggi dan mempunyai nilai jual yang tinggi.

2) Untuk menghasilkan produk yang trendpada masanya.

3) Untuk membuat produk seekonomis mungkin dalam penggunaan bahan baku dan biaya-biaya dengan tanpa mengurangi nilai jual produk tersebut.

\section{Aspek Desain Produk}

Kotler dan Keller (2016) menyatakan bahwa banyak sekali aspek-aspek rancangan atau desain produk yang mencakup bentuk, fitur, mutu kesesuaian, daya tahan, kehandalan, gaya, dan kemudahan perbaikan. Berikut merupakan penjelasan dari masing-masing aspek :

1) Bentuk (Form). Banyak produk dapat dibedakan dalam bentuk, ukuran, model atau struktur fisik produk.

2) Fitur (Features). Sebagian besar produk dapat ditawarkan dengan berbagai fitur yang melengkapi fungsi dasar mereka atau keistimewahan tambahan. Sebuah perusahaan dapat mengidentifikasi dan memilih fitur-fitur baru yang sesuai dengan survei pembeli barubaru ini dan kemudian menghitung nilai pelanggan 
terhadap biaya perusahaan untuk setiap fitur potensial. Pemasar harus mempertimbangkan berapa banyak orang ingin setiap fitur, berapa lama waktu yang dibutuhkan untuk memperkenalkan itu, dan apakah pesaing bisa dengan mudah menyalin itu.

3) Mutu Kinerja (Performance Quality). Merupakan tingkat berlakunya karakteristik dasar produk. Sebagian besar produk dibangun berdasarkan dari salah satu level kinerja, yaitu : rendah, rata-rata, tinggi, dan unggul dimana perusahaan menyesuaikan level kinerja dengan pasar sasaran dan pesaingnya.

4) Mutu Kesesuaian (Conformance quality). Merupakan tingkat kesesuaian dan pemenuhan semua unit yang diproduksi terhadap spesifikasi yang dijanjikan. Produk didesain dan dioperasikan berdasarkan karakteristik yang mendekati standar produk untuk memenuhi spesifikasi yang diminta.

5) Daya tahan (Durability). Merupakan suatu ketahanan pada suatu produk atau suatu ukuran usia operasi produk yang diharapkan dalam kondisi normal atau berat yang merupakan atribut berharga untuk suatu produk tertentu.

6) Keandalan (Reability). Merupakan ukuran kemungkinan bahwa suatu produk tidak akan rusak atau gagal pada periode tertentu dan sifat nya tidak terlihat. Suatu produk dikatakan baik akan memiliki keandalan sehingga dapat digunakan dalam jangka waktu yang lama.

7) Kemudahan perbaikan (Repairability). Merupakan ukuran kemudahan untuk memperbaiki produk ketika produk itu rusak yang ukurannya dapat dilihat melalui nilai dan waktu yang dipakai.

8) Gaya (style). Gaya yakni cara lain untuk menambah nilai pelanggan adalah melalui gaya dan desain produk yang berbeda. Gaya hanya menggambarkan penampilan produk. Gaya bisa menarik atau bahkan membosankan. Gaya sensasional bisa menarik perhatian dan menghasilkan estetika yang indah, tetapi gaya tersebut tidak benar-benar membuat kinerja produk menjadi lebih baik. Tidak seperti gaya, desain lebih dari sekedar kulit luar desain adalah jantung produk.

\section{Strategi Desain Produk}

Strategi desain produk berkaitan dengan tingkat standarisasi produk yang akan dibuat oleh perusahaan. Menurut Fandy Tjiptono (2008) perusahaan memiliki tiga pilihan strategi yaitu produk standar, customized product dan produk standar dengan modifikasi. Tujuan strategi tersebut adalah :

1) Produk standar untuk meningkatkan skala ekonomis perusahaan melalui produksi massa.

2) Customized product untuk bersaing dengan produsen produksi massa (produkstandar) melalui fleksibilitas desain produk.

3) Produk standar dengan modifikasi untuk mengkombinasi manfaat dari 2 strategi di atas.

Agar dapat menjalankan ketiga strategi di atas dengan baik, diperlukan analisis secara mendalam terhadap faktor produk dan pasar, serta perubahan lingkungan, khususnya perubahan teknologi.

\section{Keputusan Pembelian \\ Pengertian Keputusan Pembelian}

Kotler (2011) menyatakan keputusan pembelian adalah tindakan dari konsumen untuk mau membeli atau tidak terhadap produk. Dari berbagai faktor yang mempengaruhi konsumen dalam melakukan pembelian suatu produk atau jasa, biasanya konsumen selalu mempertimbangkan kualitas, harga dan produk sudah yang sudah dikenal oleh masyarakat. Keputusan pembelian adalah sebuah keputusan pembelian yang dilakukan oleh konsumen merupakan kumpulan dari sejumlah tahap keputusan. Selanjutnya menurut Kotler (2014) keputusan pembelian konsumen yaitukeputusan akhir perorangan dan rumah tangga yang membeli barang dan jasa untuk konsumsi pribadi.

\section{Model dan Pengambilan Keputusan}

Setiap individu pasti memiliki cara pandang yang berbeda-beda, cara pandang tersebut mempengaruhi konsumen dalam pengambilan keputusan. Menurut Schiffman dan Kanuk (2007) dalam buku Ujang Sumarwan (2011) menjelaskan terdapat empat model konsumen yaitu : 1) Manusia Ekonomi. Manusia dipandang sebagai individu yang melakukan keputusan secara rasional. Manusia ekonomi berusaha mengambil keputusan yang memberikan kepuasan maksimum. Keputusan berdasarkan pertimbangan-pertimbangan ekonomi, seperti harga, jumlah barang, utilitas marjinal, dan kurva indifferen.

2) Manusia Pasif. Model ini menggambarkan manusia sebagai individu yang mementingkan diri sendiri dan menerima berbagai macam promosi yang ditawarkan pemasar.

3) Manusia Koognitif. Model manusia kognitif menggambarkan konsumen sebagai individu yang berfikir untuk memecahkan masalah (a thinking problem solver).

4) Manusia Emosional. Model ini menggambarkan konsumen sebagai individu yang memiliki perasaan mendalam dan emosi yang mempengaruhi pembelian atau pemilikan barang-barang tertentu.

\section{Metode Penelitian \\ Jenis Penelitian}

Jenis penelitian ini adalah penelitian deskriptif yaitu metode yang memberikan penjelasan untuk melihat pengaruh antara variabel kualitas produk, promosi dan desain terhadap keputusan pembelian kendaraan bermotor Yamaha Mio pada PT. Hasjrat Abadi Kota Jayapura. Menurut Punaji Setyosari (2010) penelitian deskriptif adalah Penelitian yang bertujuan untuk menjelaskan atau mendeskripsikan suatu keadaan, peristiwa, objek apakah orang, atau segala sesuatu yang terkait dengan variabelvariebel yang bisa dijelaskan baik dengan angka-angka maupun kata-kata.

\section{Metode Analisis Data}

1. Metode Kualitatif

Melalui pengolahan data yang diperoleh dari pengamatan, wawancara dan kuisioner. Dari data yang terkumpul dilakukan pengolahan data melalui statistik atau matematik yang terkumpul dari data sekunder 
ataupun data primer guna mengukur besarnya pengaruh variabel bebas terhadap variabel terikat. Analisis data dalam penelitian kualitatif dilakukan bersamaan dengan proses pengumpulan data sampai diperoleh suatu kesimpulan, sehingga analisis data tersebut dapat mencapai tujuan yang diinginkan (Saryono, 2010).

2. Metode Kuantitatif

Metode kuantitatif adalah metode pengolahan data melalui metode statistik atau matematik yang terkumpul dari data sekunder ataupun data primer. Dalam penelitian ini metode kuantitatif digunakan dalam mengukur besarnya pengaruh variabel bebas terhadap variabel terikat dengan tahapan sebagai berikut :

a. Uji ini $\begin{gathered}\text { Uji Validitas } \\ \text { dilakukan dengan cara }\end{gathered}$ membandingkan angka $r_{\text {hitung }}$ dan $r_{\text {tabel }}$. Jika $r_{\text {hitung }}$ lebih besar dari $r_{\text {tabel}}$, maka item dikatakan valid dan sebaliknya jika $r_{\text {hitung }}$ lebih kecil dari $r_{\text {tabel, }}$ maka item dikatakan tidak valid. $r_{\text {hitung dicari dengan }}$ menggunakan program SPSS, sedangkan $r_{\text {tabel }}$ dicari dengan cara melihat tabel $\mathrm{r}$ minimal adalah 0,3 . (Sugiyono, 2011).

b.

$$
\text { Uji Reliabilitas }
$$

Uji ini dilakukan dengan cara membandingkan angka cronbach alpha dengan ketentuan milai cronbach alpha minimal adalah 0,60 artinya jika nilai cronbach alpha yang didapatkan dari hasil perhitungan SPSS lebih besar dari 0,60, maka disimpulkan kuesioner tersebut reliable, sebaliknya jika cronbach alpha lebih kecil dari 0,6 maka disimpulkan reliabel. (Sugiyono, 2011).

c.

1) Uji Normalitas

Normalitas dapat dilihat dengan menggunakan kurva histogram. Data dapat dikatakan normal jika bentuk kurva memiliki kemiringan yang cenderung imbang, baik pada sisi kiri maupun sisi kanan, dan kurva berbentuk mempunyai lonceng yang hampir sempurna (Nugroho, 2005).

2) Uji Multikolinearitas

Deteksi Multikolinieritas pada suatu model dapat dilihat dari nilai tolerance dan lawannya Variance Inflation Factor (VIF). Kedua ukuran ini menunjukan setiap variabel bebas manakah yang dijelaskan oleh variabel bebas lainnya. Dalam pengertian sederhana setiap variabel bebas menjadi variabel terikat dan di regres terhadap variabel bebas lainnya. Tolerance mengukur variabilitas variabel bebas yang telah terpilih yang tidak dapat dijelaskan oleh variabel bebas lainnya. Jadi nilai tolerance rendah sama dengan nilai VIF tinggi (karena $\mathrm{VIF}=1 /$ tolerance) dan menunjukkan adanya kolinearitas yang tinggi. Nilai Cut Off yang umum dipakai adalah nilai tolerance $<0,10$ atau sama dengan nilai VIF $>10$. Setiap peneliti harus menentukan tingkat kolinearitas yang masih dapat ditolelir (Imam Ghozali, 2006).

3) Uji Heteroskedastisitas

Menurut Imam Ghozali (2006) Uji Heteroskedastisitas bertujuan untuk menguji apakah dalam model regresi terjadi ketidak samaan variancedari residual satu pengamatan ke pengamatan lain. Jika variance dari residual suatu pengamatan ke pengamatan lain tetap, maka disebut Homoskedastisitas atau tidak terjadi Heteroskedastisitas. Cara memprediksi ada tidaknya Homoskedastisitas pada suatu model dapat dilihat pada gambar scatterplot.

4) Analisis Regresi Linear Berganda

Uji Analisis Regresi Linear Berganda bertujuan untuk menguji hubungan pengaruh antara satu variabel terhadap variabel lain. Variabel yang dipengaruhi disebut variabel tergantung atau dependen, sedangkan variabel yang mempengaruhi disebut variabel bebas atau variabel independent (Nugroho, 2005). Adapun rumus analisis regresi linear berganda adalah sebagai berikut :

$$
\mathrm{Y}=\mathrm{a}+\mathrm{b} 1 \mathrm{X} 1+\mathrm{b} 2 \mathrm{X} 2+\mathrm{b} 3 \mathrm{X} 3+\mathrm{e}
$$

Dimana :

$$
\begin{aligned}
& \mathrm{Y} \quad=\text { Keputusan Pembelian } \\
& \mathrm{X} 1=\text { Kualitas Produk } \\
& \mathrm{X} 2 \quad=\text { Promosi } \\
& \mathrm{X} 3=\text { Desain } \\
& \mathrm{b} 1, \mathrm{~b} 2, \mathrm{~b} 3=\text { Koefisien Regresi } \\
& \text { a } \quad=\text { Konstanta } \\
& \text { e }=\text { Error }
\end{aligned}
$$

Dalam analisis ini teknik mencari regresi berganda dengan menggunakan output program SPSS (statistical package for social science) versi 22.0.

5) Uji Parsial (Uji t)

Menurut Sugiyono (2004) untuk menguji variabel bebas secara satu persatu ada atau tidaknya pengaruh terhadap variabel terikat (Y). Pegujian secara parsial (Uji t) digunakan untuk menguji hipotesis pengaruh variabel bebas secara parsial terhadap variabel terikat. Dengan taraf signifikansi yang digunakan adalah $5 \%$ atau $\alpha=0.05$.

6) Uji Simultan (Uji F)

Uji F dilakukan untuk mengetahui apakah variabel independen berpengaruh positif dan signifikan secara bersama-sama terhadap variabel dependen. Kaidah pengujian signifikan dengan program SPSS adalah :

a. Jika nilai probabilitas 0,05 lebih kecil atau sama dengan nilai probabilitas signifikan atau $(0,05 \leq \mathrm{sig})$, maka Ho diterima dan $\mathrm{H}_{1}$ ditolak, artinya tidak signifikan.

b. Jika nilai probabilitas 0,05 lebih besar atau sama dengan nilai probabilitas signifikan atau $(0,05 \geq \operatorname{sig})$, maka Ho ditolak dan $\mathrm{H}_{1}$ 
diterima, artinya signifikan. (Sugiyono, 2008).

Pengujian Regresi Dan Hipotesis

1. Hasil Analisis Regresi Linier Berganda
Berdasarkan dengan hasil pengolahan data dengan menggunakan program SPSS 22.0 for windows, maka diperoleh hasil sebagai berikut :

\begin{tabular}{|c|c|c|c|c|c|c|c|}
\hline & \multicolumn{4}{|c|}{ Coefficients $^{a}$} & & & \\
\hline \multirow[b]{2}{*}{ Model } & \multicolumn{2}{|c|}{$\begin{array}{c}\text { Unstandardized } \\
\text { Coefficients }\end{array}$} & \multirow{2}{*}{$\begin{array}{c}\text { Standar } \\
\text { dized } \\
\text { Coeffici } \\
\text { ents } \\
\text { Beta }\end{array}$} & \multirow[b]{2}{*}{$\mathrm{t}$} & \multirow[b]{2}{*}{ Sig. } & \multicolumn{2}{|c|}{$\begin{array}{c}\text { Collinearity } \\
\text { Statistics }\end{array}$} \\
\hline & B & $\begin{array}{l}\text { Std. } \\
\text { Error }\end{array}$ & & & & $\begin{array}{l}\text { Tolera } \\
\text { nce }\end{array}$ & VIF \\
\hline 1 (Constant) & 3,128 & ,648 & & 4,831 & ,000 & & \\
\hline $\begin{array}{l}\text { Kualitas } \\
\text { Produk }\end{array}$ & ,417 & ,043 &, 588 & 9,716 & ,000 & ,241 & 4,154 \\
\hline Promosi &, 147 & ,067 &, 134 & 2,184 & 033 & ,233 & 4,288 \\
\hline Desain & ,224 & ,047 & ,298 & 4,780 & ,000 & ,228 & 4,393 \\
\hline
\end{tabular}

a. Dependent Variable: Keputusan Pembelian

Sumber : Data diolah, 2020

Tabel tersebut di atas menunjukkan bahwa model persamaan regresi sebagai berikut :

$\mathrm{Y}=3,128+0,417 \mathrm{X}_{1}+0,147 \mathrm{X}_{2}+0,224 \mathrm{X}_{3}+\mathrm{e}$

Persamaan di atas memberikan implementasi bahwa :

a) Konstanta sebesar 3,128; artinya jika kualitas produk $\left(\mathrm{X}_{1}\right)$, promosi $\left(\mathrm{X}_{2}\right)$ dan desain $\left(\mathrm{X}_{3}\right)$ dengan asumsi bahwa nilainya tetap atau 0 , maka keputusan pembelian (Y) mengalami peningkatan sebesar 3,128 .

b) Koefisien regresi variabel kualitas produk $\left(\mathrm{X}_{1}\right)$ sebesar 0,417; artinya jika variabel bebas lain nilainya tetap dan kualitas produk $\left(\mathrm{X}_{1}\right)$ mengalami kenaikan 1 satuan, maka keputusan pembelian (Y) akan mengalami peningkatan sebesar 0,417. Koefisien bernilai positif artinya terjadi hubungan positif antara kualitas produk dengan keputusan pembelian, semakin baik kualitas produk, maka akan semakin baik pula keputusan pembelian.

c) Koefisien regresi variabel promosi $\left(\mathrm{X}_{2}\right)$ sebesar 0,147 , artinya jika variabel bebas lain nilainya tetap dan promosi $\left(\mathrm{X}_{2}\right)$ mengalami kenaikan 1 satuan, maka kualitas produk (Y) akan mengalami peningkatan sebesar 0,147. Koefisien bernilai positif artinya terjadi hubungan positif antara promosi dengan kualitas produk, semakin baik promosi, maka semakin meningkatkan keputusan pembelian.

d) Koefisien regresi variabel desain $\left(X_{3}\right)$ sebesar 0,224, artinya jika variabel bebas lain nilainya tetap dan desain $\left(\mathrm{X}_{3}\right)$ mengalami kenaikan 1 satuan, maka keputusan pembelian (Y) akan mengalami peningkatan sebesar 0,224. Koefisien bernilai positif artinya terjadi hubungan positif antara desain dengan keputusan pembelian, semakin baik desain, maka semakin meningkat pula keputusan pembelian.

2. Pengujian Hipotesis

a. Pengujian Hipotesis Parsial (Uji t)

1) Pengaruh kualitas produk terhadap keputusan pembelian kendaraan bermotor yamaha mio pada
PT. Hasjrat Abadi Kota Jayapura. Hasil analisis diperoleh nilai $t_{\text {hitung }}$ sebesar 9,716 nilai sig ( $p$ signifikan) sebesar 0.000. nilai $\mathrm{t}_{\text {tabel }}$ sebesar 1,670. Dengan demikian nilai sig ( $p$ signifikan) $0,000<$ 0.05 (alpha yang dipersyaratkan) maka $\mathrm{H}_{0}$ ditolak dan $\mathrm{H}_{\mathrm{a}}$ diterima yaitu kualitas produk mempunyai pengaruh positif dan signifikan terhadap keputusan pembelian kendaraan bermotor yamaha mio pada PT. Hasjrat Abadi Kota Jayapura. Artinya semakin baik kualitas produk yang dimiliki, maka akan meningkatkan keputusan pembelian.

2) Pengaruh promosi terhadap keputusan pembelian kendaraan bermotor yamaha mio pada PT. Hasjrat Abadi Kota Jayapura. Hasil analisis diperoleh nilai $\mathrm{t}_{\text {hitung }}$ sebesar 2,184 nilai sig ( $p$ signifikan) sebesar 0.033. nilai $\mathrm{t}_{\text {tabel }}$ sebesar 1,670. Dengan demikian nilai sig ( $p$ signifikan) $0,033<0.05$ (alpha yang dipersyaratkan) maka $\mathrm{H}_{0}$ ditolak dan $\mathrm{H}_{\mathrm{a}}$ diterima yaitu promosi mempunyai pengaruh positif dan signifikan terhadap keputusan pembelian kendaraan bermotor yamaha mio pada PT. Hasjrat Abadi Kota Jayapura. Artinya semakin baik promosi dilaksanakan maka akan meningkatkan keputusan pembelian.

3) Pengaruh desain terhadap keputusan pembelian kendaraan bermotor yamaha mio pada PT. Hasjrat Abadi Kota Jayapura. Hasil analisis diperoleh nilai $\mathrm{t}_{\text {hitung }}$ sebesar 4,780 nilai sig ( $p$ signifikan) sebesar 0.000 . nilai $\mathrm{t}_{\text {tabel }}$ sebesar 1,670. Dengan demikian nilai sig ( $p$ signifikan) $0,000<0.05$ (alpha yang dipersyaratkan) maka $\mathrm{H}_{0}$ ditolak dan $\mathrm{H}_{\mathrm{a}}$ diterima yaitu desain mempunyai pengaruh positif dan signifikan terhadap keputusan pembelian pada PT. Hasjrat Abadi Kota Jayapura. Artinya semakin baik desain produk maka akan meningkatkan keputusan pembelian.

\section{b. Pengujian Hipotesis Simultan (Uji F)}

Uji $F$ digunakan untuk mengetahui tingkat signifikansi pengaruh variabel-variabel independen secara bersama-sama (simultan) terhadap variabel dependen. Uji $\mathrm{F}$ dilakukan dengan cara 
membandingkan antara nilai Fhitung dengan Ftabel. Dengan kaidah pengujian signifikansi : jika $\mathrm{F}_{\text {hitung }}>$ $\mathrm{F}_{\text {tabel}}$, maka Ho ditolak artinya signifikan, jika $\mathrm{F}_{\text {hitung }}<$
$\mathrm{F}_{\text {tabe }} \mathrm{l}$, maka Ho diterima artinya tidak signifikan. Dengan taraf signifikan $\mathrm{a}=0,05$, maka didapat $\mathrm{F}_{\text {tabel }}=$ 2,76 .

\begin{tabular}{|c|c|c|c|c|c|}
\hline Model & Sum of Squares & $\overline{d f}$ & Mean Square & $\mathrm{F}$ & Sig. \\
\hline 1 Regression & 399,133 & 3 & 133,044 & 357,313 &, $000^{\mathrm{b}}$ \\
\hline Residual & 22,713 & 61 & ,372 & & \\
\hline Total & 421,846 & 64 & & & \\
\hline
\end{tabular}

a. Dependent Variable: Keputusan Pembelian

b. Predictors: (Constant), Desain, Kualitas Produk, Promosi

Sumber : Data diolah, 2020

Pengaruh kualitas produk, promosi dan desain secara simultan berpengaruh terhadap keputusan pembelian kendaraan bermotor yamaha mio pada PT. Hasjrat Abadi Kota Jayapura. Berdasarkan tabel tersebut di atas bahwa perbandingan nilai $\mathrm{F}_{\text {hitung }}>\mathrm{F}_{\text {tabel }}$, yaitu 357,313>2,76 dengan nilai signifikan $.000^{\mathrm{b}}$ maka Ho ditolak Ha diterima. Berarti terdapat pengaruh kualitas produk, promosi dan desain secara simultan terhadap keputusan pembelian kendaraan bermotor yamaha mio pada PT. Hasjrat Abadi Kota Jayapura.

\section{Kesimpulan}

1. Kualitas produk berpengaruh positif dan signifikan terhadap keputusan pembelian kendaraan bermotor yamaha mio pada PT. Hasjrat Abadi Kota Jayapura. Dengan demikian hipotesis pertama yaitu diduga bahwa kualitas produk berpengaruh positif dan signifikan terhadap keputusan pembelian kendaraan bermotor yamaha mio pada PT. Hasjrat Abadi Kota Jayapura dapat diterima. Hal ini berarti semakin baik kualitas produk yang dimiliki, maka akan meningkatkan keputusan pembelian kendaraan bermotor yamaha mio pada PT. Hasjrat Abadi Kota Jayapura.

2. Promosi berpengaruh positif dan signifikan terhadap keputusan pembelian kendaraan bermotor Yamaha mio pada PT. Hasjrat Abadi Kota Jayapura. Sehingga hipotesis kedua yang menyatakan promosi berpengaruh positif dan signifikan terhadap keputusan pembelian kendaraan bermotor Yamaha mio pada PT. Hasjrat Abadi Kota Jayapura dapat diterima. Hal ini berarti bahwa semakin baik promosi dilaksanakan maka akan meningkatkan keputusan pembelian.

3. Desain berpengaruh positif dan signifikan terhadap keputusan pembelian kendaraan bermotor yamaha mio pada PT. Hasjrat Abadi Kota Jayapura. Sehingga hipotesis ketiga yang menyatakan desain berpengaruh positif dan signifikan terhadap keputusan pembelian kendaraan bermotor Yamaha mio pada PT. Hasjrat Abadi Kota Jayapura dapat diterima. Hal ini menunjukkan bahwa semakin baik desain produk maka akan meningkatkan keputusan pembelian.

4. Kualitas produk, promosi dan desain secara simultan berpengaruh positif dan signifikan terhadap keputusan pembelian kendaraan bermotor yamaha mio pada PT. Hasjrat Abadi Kota Jayapura. Sehingga hipotesis keempat yang menyatakan bahwa kualitas produk, promosi dan desain secara simultan berpengaruh positif dan signifikan terhadap keputusan pembelian kendaraan bermotor yamaha mio pada PT. Hasjrat Abadi Kota Jayapura dapat diterima. Hal ini berarti semakin baik kualitas produk, promosi dan desain yamaha mio pada PT. Hasjrat Abadi Kota Jayapura, maka akan sebaik pula keputusan pembelian Yamaha mio pada PT. Hasjrat Abadi Kota Jayapura.

\section{Daftar Pustaka}

Argarini, Novia. 2008. Strategi Promosi. PT. Tigawarna pada Semarang Expo. lib.ui.ac.id. Jakarta.

Ariani, Dorothea Wahyu, 2003. Manajemen Kualitas Pendekatan Sisi Kualitatif. Ghalia Indonesia: Jakarta.

Ghozali, Imam. 2006. Aplikasi Analisis Multivariate dengan Program SPSS (Edisi Ke 4). Badan Penerbit Universitas Diponegoro. Semarang.

https://aripitstop.com/2020/01/21/intip-data-penjualanmotor-di-indonesia-tahun-2017-2019kapan-penjualan-honda-bisa-turun/

Husein, Umar. 2011. Metode Penelitian Untuk Skripsi dan Tesis Bisnis Edisi 11. PT Raja Grafindo Persada. Jakarta.

Kasmir. 2005. Pemasaran Jasa. Graya Grafindo Persada. Jakarta.

Kotler, Amstrong. 2001. Prinsip-prinsip pemasaran, Edisi keduabelas, Jilid 1. Erlangga. Jakarta.

Kotler, dan Keller. 2012. Manajemen Pemasaran. Edisi 12. Erlangga: Jakarta.

Kotler, Philip and Keller, Kevin Lane. 2016. Marketing Management, 15th Edition, Pearson Education, Inc. London.

Kotler, Philip dan Amstrong, Gary. 2014. Principles of Marketing, 12th Edition, Jilid 1 Terjemahan Bob Sabran. Erlangga. Jakarta.

Kotler, Philip. 2003. Manajemen Pemasaran. Edisi kesebelas. Indeks kelompok Gramedia. Jakarta.

Kotler, Philip. 2008. Manajemen Pemasaran Edisi 12 Jilid 2. Indeks. Jakarta.

Lupiyoadi, Rambat. 2013. Manajemen Pemasaran Jasa Berbasis Kompetensi (Edisi 3). Salemba Empat. Jakarta. 
Nugroho, Agung. 2005. Strategi Jitu Memilih Metode Statistic Penelitian Dengan SPSS, Andi Yogyakarta, Yogyakarta.

Schiffman, Leon.G. dan Kanuk, Leslie Lazar. 2007. Perilaku Konsumen. Edisi Ke-7. Diterjemahkan oleh Zoelkifli Kasip. PT. Indeks, Jakarta.

Setyosari, Punaji. 2010. Metode Penelitian dan Pengembangan. Kencana. Jakarta.

Sugiyono. 2004. Metode Penelitian. Alfabeta. Bandung.

Sugiyono. 2008. Metode Penelitian Kuantitatif Kualitatif dan $R \& D$. ALFABETA. Bandung.

Sugiyono. 2011. Metode penelitian kuntitatif kualitatif dan $R \& D$. Alfabeta. Bandung.

Sumarwan, Ujang. 2011. Perilaku Konsumen : Teori dan Penerapannya dalam Pemasaran. Ghalia Indonesia. Bogor.

Tjiptono, Fandy. 2008. Strategi Pemasaran, Edisi 3, ANDI: Yogyakarta.

Tjiptono, Fandy. 2012. Strategi Pemasaran, ed. 3, Andi : Yogyakarta.

Tjiptono, Fandy. 2015. Strategi Pemasaran, Edisi 4, Penerbit Andi, Yogyakarta.

Ulrich K.T, Eppinger S.D. 2008. Perancangan dan Pengembangan Produk. Salemba Teknika. Jakarta. 